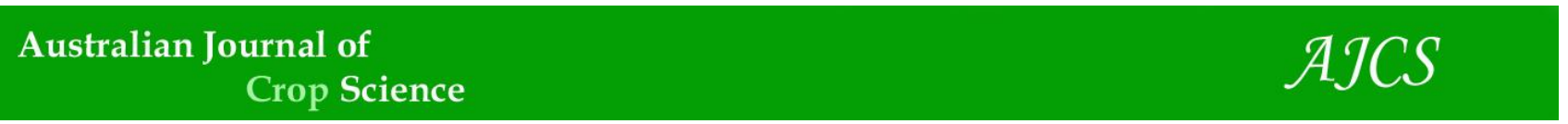

AJCS 14(10):1583-1588 (2020)

ISSN:1835-2707

doi: 10.21475/ajcs.20.14.10.p2364

\title{
Sexual propagation of common Bahia cocoa seedlings (Theobroma cacao L.) influenced by irrigation depths and the planting seasons
}

\author{
Robson Prucoli Posse ${ }^{1}$, Vinicius de Souza Oliveira ${ }^{2}$, Francielly Valani ${ }^{1}$, Stefany Sampaio Silveira ${ }^{1}$, Sophia \\ Machado Ferreira da Silva ${ }^{1}$, Carlos Alberto Spaggiari Souza ${ }^{3}$, Sheila Cristina Prucoli Posse ${ }^{4}$, Geilson Silva \\ Costa ${ }^{1}$, Edilson Romais Schmildt ${ }^{2}$
}

\author{
${ }^{1}$ Federal Institute of Espírito Santo - Campus Itapina, Colatina, Espírito Santo, Brazil \\ ${ }^{2}$ Federal University of Espírito Santo - Center Noth of Espírito Santo, São Mateus, Espírito Santo, Brazil \\ ${ }^{3}$ Cacao Research Station “Filogônio Peixoto" - CEPLAC, Linhares, Espírito Santo, Brazil \\ ${ }^{4}$ Capixaba Institute for Research, Technical Assistance and Rural Extension, Vitória, ES, Brazil
}

\begin{abstract}
Cocoa (Theobroma cacao L.) is one of the most economically important species due to its use in the production of chocolate, honey, pulp, animal feed, fertilizers, jellies, butter and cocoa powder. The production of seedlings such as through sexual propagation is the essential stage for the establishment of new cocoa crops, in which the seedlings are produced by seeds. This is the most commonly used method in cocoa. Several factors interfere with the final quality of the seedlings, such as the planting season and the irrigation management. Thus, the objective of this study was to evaluate the effects of different irrigation depths and planting seasons on the quality and growth of Bahia genotype cocoa seedlings produced through sexual propagation. The study took place at the Federal Institute of Espírito Santo, Campus Itapina, in Colatina, located in the Northwest region of the State of Espírito Santo, Brazil. The experimental design was completely randomized in a split-plot scheme. The plots consisted of six different irrigation depths: 4, 6, 8, 10, 12 and $14 \mathrm{~mm} \mathrm{~d}^{-1}$ and the subplots, of three different planting seasons: autumn, winter and spring. At 50 days after sowing, the seedlings were evaluated for the following morphological characteristics: plant height, stem diameter, leaf area, length of the root system, dry mass of the aerial part, dry mass of the root system, total dry mass and Dickson quality index. The production of Common Bahia genotype cacao seedlings is more effective in the irrigation depth of $9.44 \mathrm{~mm} \mathrm{~d}^{-1}$, demonstrating better development and higher plant quality.
\end{abstract}

Keywords: Theobroma cacao L., efficiency of water use; ideal conditions of cultivation, seedling quality, Dickson quality index. Abbreviations: PH_Plant Height, SD_Stem Diameter, LA_Leaf Area, LRS_Length of the Root System, DMAP_Dry Mass of the Aerial Part, DMRS_Dry Mass of the Root System, TDM_Total Dry Mass, DQI_Dickson Quality Index.

\section{Introduction}

The cocoa (Theobroma cacao L.) is a tropical species originating from the Amazon Basin belonging to the Malvaceae family. It is one of the most cultivated and economically important crops because its fruits are used for chocolate production, as well as other by-products such as honey, pulp, animal feed, fertilizers, jellies, butter and cocoa powder (Lahive et al., 2018; Lima et al., 2018). Brazil ranks in the sixth position as the world's largest producer (Agrianual, 2017), with a planted area in the 2018 harvest of 580,295 hectares and a total production of 250,308 tons (IBGE, 2019).

Among the different forms of propagation of cocoa, the most common is the sexual, in which the seedlings are produced by seeds (Sodré and Morocco, 2009). This option is a result of the easy way found by producers to handle seed-derived plants and, mainly, due to the good production of hybrids and cultivated varieties (Dias, 2001). Several factors can interfere with the final quality of seedlings produced in greenhouses, such as the planting season and irrigation.
During irrigation, the problem can be caused by the poor distribution of the water or its management, causing lack or excess of irrigation. During stress condition, the water limits the cellular expansion, absorption of nutrients, which causes a decrease of the leaf area and photosynthetic process (Taiz et al., 2017). When water applied in excess, it causes substrate flooding, favors the appearance of phytosanitary problems and may lead to leaching of nutrients, in addition to generating water and plant wastes (Lopes et al., 2007). The planting season is another important factor in the process of seedling development due to temperature, considering that the cacao crop requires optimal temperature ranges for its growth, which can be variable during different periods of the year (Hadley et al., 1994).

Thus, studies and the establishment of protocols are necessary for the production of seedlings of Theobroma cacao L. that allow the use of water in a sustainable manner, quantifying its application in an appropriate way, besides the definition of the season for its cultivation aiming at the best conditions for the development of plants. 
In this way, the objective of this study was to evaluate the effects of different irrigation depths and the planting seasons on the quality and growth of Bahia cocoa seedlings produced through sexual propagation.

\section{Results and discussion}

\section{Plant growth under applied irrigation depth}

No significant effect was observed between the applied irrigation depth and the planting seasons. Therefore, we accepted the average value presented for each depth in the three evaluated seasons. For the relation between the characteristics of the plant and irrigation depth, the only characteristic that did not differ statistically by the test $\mathrm{F}$ at $5 \%$ of probability was the plant height, using an average value for this characteristic according to the applied depths. There were significant differences for all the other characteristics analyzed, attributed to different planting seasons, in which the seedlings were conducted.

The behavior of the seedling growth characteristics in relation to the applied irrigation depth are represented in Fig 1. Regarding the plant height, the seedlings presented an average of $15.5 \mathrm{~cm}$ in all irrigation depths (Fig 1A). The stem diameter had a quadratic adjustment, with a maximum point of $4.25 \mathrm{~mm}$ in the $10.73 \mathrm{~mm} \mathrm{~d}^{-1}$ depth and coefficient of determination $\left(R^{2}\right)$ of 0.9303 (Fig 1B). The leaf area showed a quadratic effect, with $R^{2}$ of 0.9386 and maximum point of $264.82 \mathrm{~cm}^{2}$ in the $9.41 \mathrm{~mm} \mathrm{~d}^{-1}$ depth (Fig 1C). For the length of the root system, the observed adjustment was quadratic with $R^{2}$ of 0.7894 . The maximum point of $22.02 \mathrm{~cm}$ was observed in the irrigation depth of $9.94 \mathrm{~mm} \mathrm{~d}^{-1}$ (Fig. 1D).

\section{Phytomass and quality in relation to the applied irrigation depth}

The adjusted equations for the characteristics related to phytomass and quality of the seedlings can be seen in Fig 2 . The dry mass of the aerial part showed a quadratic adjustment with a maximum point of $1.36 \mathrm{~g}$ in the irrigation depth of $9.53 \mathrm{~mm} \mathrm{~d}^{-1}$ and $\mathrm{R}^{2}$ of 0.7677 (Fig 2A). The dry mass of the root system had a quadratic behavior and a maximum point of $0.30 \mathrm{~g}$ in the irrigation depth of $9.46 \mathrm{~mm} \mathrm{~d}^{-1}$, with $\mathrm{R}^{2}$ of 0.9120 (Fig 2B). The total dry mass presented quadratic effect with a maximum point of $1.66 \mathrm{~g}$ in the irrigation depth of $9.50 \mathrm{~mm} \mathrm{~d}^{-1}$ and $\mathrm{R}^{2}$ of 0.8175 (Fig 2C). The Dickson quality index presented a quadratic behavior for the two cultivars analyzed, with a maximum point of 0.20 in the irrigation depth of $9.44 \mathrm{~mm} \mathrm{~d}^{-1}$ and $\mathrm{R}^{2}$ of 0.8841 (Fig 2D).

\section{Development and quality in relation to the applied irrigation depth}

In general, except for plant height, all other characteristics had interference from the applied irrigation depth. The shortage or excess of water influenced the development and quality of Common Bahia cultivar. The lack of water due to the smallest irrigation depths available to the seedlings caused a reduction in the characteristics analyzed. In the same way, the excess was detrimental to the cacao seedlings interfering negatively in the evaluated characteristics, attesting loss of the quality of the seedlings.

During the water deficit, the plants close their stomata, reducing gas exchange (Araque et al., 2012). This stomatal closure is induced by the accumulation of abscisic acid $(A B A)$. This mechanism aims to reduce water loss through transpiration. On the other hand, it limits the process of photosynthesis, and consequently, the production of assimilates, reducing the development of the plants (Taiz et al., 2017). Under conditions of lack of water, the cell wall of plants loses the capacity of expansion due to the lack of turgescence and to the hormonal imbalance, directly affecting the growth capacity of plants (Larcher, 1995)

In environments with water excess, plant roots are submitted to low amounts of oxygen and this condition limits the metabolic activities, interfering directly in their development (Taiz et al., 2017). The lack of oxygen in the substrate leads the plant roots to replace aerobic respiration by the anaerobic one that is less efficient, forcing the consumption of a greater amount of carbohydrates by the root system to maintain the functioning of the cells (Vartapetian and Jackson, 1997).

According to Taiz et al. (2017), the first symptom related to water stress is felt by the leaves. Under these conditions, the cacao tree presents a decrease of the leaf area, besides a decrease of the photosynthetic rate. The foliar area of the crops is a primordial factor in the interception of radiation, water and energy exchange, being an indicative of plant growth (Peksen, 2007). Thus, the measurement of the leaf area allows the understanding of the interaction between the development of the crop and the cultivation conditions (De Jesus et al., 2001).

In the present study, we observed that the irrigation depth with the highest leaf area indexes $\left(9.41 \mathrm{~mm} \mathrm{~d}^{-1}\right)$ is very close to the depths with the highest accumulations of dry mass of the aerial part $\left(9.53 \mathrm{~mm} \mathrm{~d}^{-1}\right)$, dry mass of the root system $\left(9.46 \mathrm{~mm} \mathrm{~d}^{-1}\right)$ and total dry mass $\left(9.50 \mathrm{~mm} \mathrm{~d}^{-1}\right)$. According to Melo et al. (2007), this feature is interesting because it indicates that a larger leaf area provides the plants a greater light uptake for photosynthesis, generating a greater amount of photoassimilates, and consequently, greater development and accumulation of dry mass. There is a strong correlation between leaf area and stem diameter, where plants with larger leaf area have larger stem diameter due to carbohydrate production, inversely to those with lower leaf index.

Binotto et al. (2010), reported that dry mass of the plant correlates with Dickson quality index. This index defines quality of seedlings, because in its formula, characteristic of growth of all the parts of the plants are considered, once the seedlings that present greater value have more capacity of survival in field conditions (Gomes et al., 2003). Therefore, we observed that the irrigation depth of $9.44 \mathrm{~mm} \mathrm{~d}^{-1}$ provided a higher value of the Dickson index, attesting higher quality of Common Bahia cultivar. It demonstrates that the availability of water plays a major role in the quality of cocoa seedlings.

\section{Planting season}

In Table 1, it is possible to observe the comparison of the averages of the physiological characteristics analyzed in relation to the planting season. 
Table 1. Average values of plant height (PH), stem diameter (SD, leaf area (LA), length of the root system (LRS), dry mass of the aerial part (DMAP), dry mass of the root system (DMRS), total dry mass (TDM) and Dickson quality index (DQI) at three planting seasons of Common Bahia cocoa seedlings.

\begin{tabular}{|c|c|c|c|c|c|c|c|c|}
\hline PLANTING SEASON & $\mathrm{PH}$ & SD & LA & LRS & DMAP & DMRS & TDM & DQI \\
\hline Autumn & $17.15 a$ & $3.85 b$ & $311.57 a$ & $15.6 c$ & $1.40 \mathrm{~b}$ & $0.25 b$ & $1.65 b$ & $0.163 b$ \\
\hline Winter & $12.19 b$ & $3.72 b$ & $126.29 b$ & $20.33 b$ & $0.70 c$ & $0.23 a b$ & $0.94 c$ & $0.140 \mathrm{~b}$ \\
\hline Spring & $17.29 a$ & $4.57 a$ & $282.45 a$ & $23.67 a$ & $1.63 a$ & $0.29 a$ & $1.93 a$ & $0.209 a$ \\
\hline
\end{tabular}

Averages followed by the same letter in the columns do not differ according to Tukey test at $5 \%$ probability.
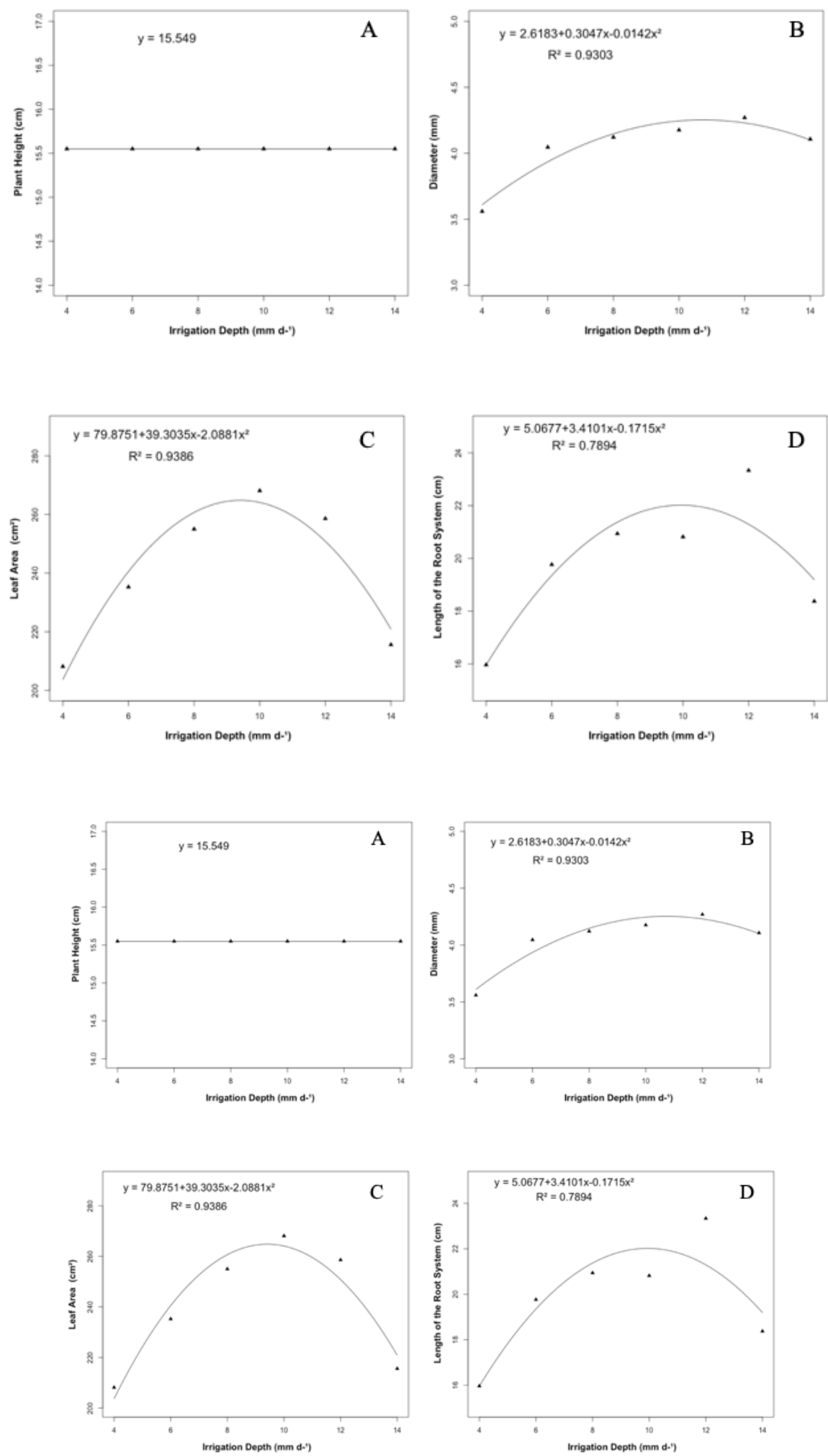

Fig 1. Behavior of plant height (A), stem diameter (B), leaf area (C) and length of the root system (D) in common Bahia cocoa seedlings submitted to different irrigation depths. 

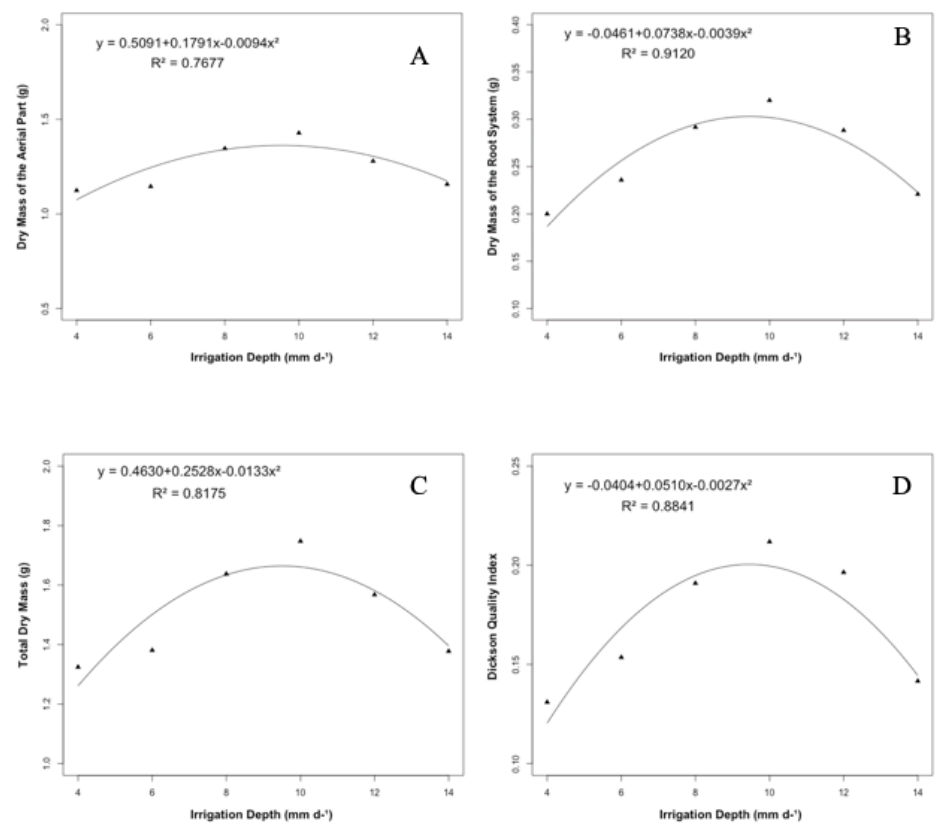

Fig 2. Adjusted equations for dry mass of the aerial part (A), dry mass of the root system (B), total dry mass (C) and Dickson quality index (D) of the Common Bahia cultivar submitted to different irrigation depths.

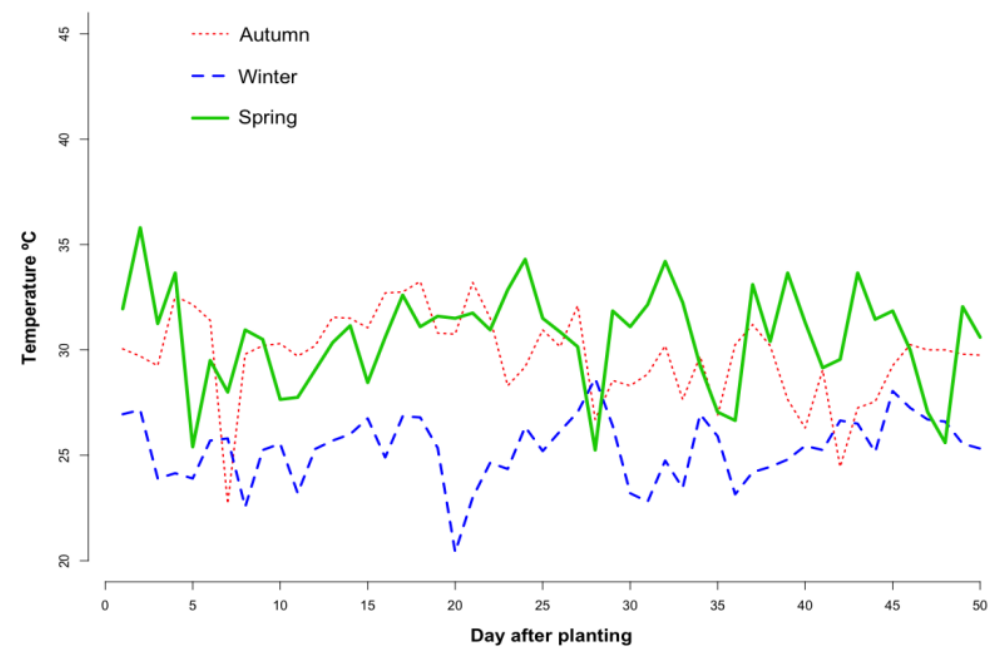

Fig 4. Average temperature inside the greenhouse during the experimental period in three planting seasons in Colatina, Espírito Santo.

We verified that planting in the spring and autumn did not differ for the plant height and leaf area significantly, with spring scoring averages statistically superior in the other characteristics studied.

The results found in the present study indicate that in the spring the Common Bahia cultivar presented better development and quality than in autumn and winter. This can be explained by the higher average temperature in spring $\left(25.3\right.$ to $35.8^{\circ} \mathrm{C}$ ) compared to winter $\left(20.4\right.$ to $28.7^{\circ} \mathrm{C}$ ) and autumn $\left(22.7\right.$ to $\left.33.3^{\circ} \mathrm{C}\right)$. Like other tropical species, the cocoa tree depends on the temperatures for its development (Hadley et al., 1994).

There is a relationship between the rise in temperature and the growth of cocoa. According to Lahive et al. (2018), there is an increase of the dry mass of the aerial part and the height of the seedlings starting from the temperature of $18 .{ }^{\circ} \mathrm{O} C$ to $33.3 \stackrel{\circ}{\circ}$, corroborating with the results found in this study. However, for the leaf area, the ideal temperature, is around 30.5 으, according to Sena Gomes and Kozlowski (1987). In the present study, although there was no significant difference, this was the only characteristic that presented higher value in autumn than spring, where the temperatures were milder.

Another important factor in spring is that, the days are longer, providing greater luminosity for the accomplishment of the photosynthesis and consequently the accumulation of photoassimilates, promoting better development and increase in the quality of the seedlings. It is verified that the highest accumulation of total dry mass, characteristic desired in agriculture, was superior in spring than in the other seasons evaluated. According to Peixoto et al. (2018), it is fundamental for agricultural species to have an absolute absorption of solar radiation, since it is responsible for producing photoassimilates, which are part of the dry 
matter of plants, being the season of the year determining in the available radiation intensity for crops. However, under environments with high light availability, cocoa plants need other resources to maintain the high photosynthetic rate and plant growth, such as nutrients and water (Lahive et al., 2018).

In short, it can be seen that the irrigation depths between 9.41 and $10.73 \mathrm{~mm} \mathrm{~d}^{-1}$ provided better results for all the evaluated characteristics, and the $9.44 \mathrm{~mm} \mathrm{~d}^{-1}$ had the highest Dickson quality index, characteristic that qualifies the cocoa seedlings. About the planting season, the spring was the most adequate, providing the best results for all characteristics evaluated. Thus, the $9.44 \mathrm{~mm} \mathrm{~d}^{-1}$ depth and spring are the most suitable for the production of Common Bahia cultivar, for presenting the best development and quality.

\section{Materials and methods}

\section{Location of the experiment}

The study took place at the Federal Institute of Espírito Santo, Campus Itapina, in Colatina, located in the Northwest of the State of Espírito Santo, Brazil, with geographic coordinates of $19^{\circ} 29^{\prime}$ South latitude and $40^{\circ} 45^{\prime}$ West longitude and with 62 meters of altitude. The climate of the region, according to Köppen (1936), is classified with Tropical Aw.

\section{Plant material}

The seeds used in the experiment were obtained from the experimental station Filogônio Peixoto, in the city of Linhares, North of the State of Espírito Santo, Brazil, obtained from completely ripe fruits of Bahia cacao, which had the mucilage removed by friction.

\section{Experimental design}

The experiment was conducted in a greenhouse, with linear dimensions of $25 \mathrm{~m} \times 5 \mathrm{~m}$ and height of $3 \mathrm{~m}$, in six individual environments, $2.20 \mathrm{~m}$ long and $1.10 \mathrm{~m}$ wide, insulated by transparent plastic canvas on the sides. Each environment was composed of six GREEN MIST anti-mist nebulizers (NaanDanJain ), located $1 \mathrm{~m}$ above the seedlings and spaced $0.8 \mathrm{~m}$ apart, with an application efficiency of $85 \%$. The irrigation frequency was distributed daily for 10 hours (from 7 a.m. to 5 p.m.), with a service pressure of $2 \mathrm{kgf} \mathrm{cm}^{-2}$, individually controlled by electronic controllers and centrifugal pumps of $0.5 \mathrm{hp}$ installed independently.

The experimental design was completely randomized in a split-plot scheme. The plots consisted of six different irrigation depths: $4,6,8,10,12$ and $14 \mathrm{~mm} \mathrm{~d}^{-1}$ and the subplots, of three different planting seasons, according to seasons of the year, for the Southern Hemisphere: autumn $(03 / 16 / 2017$ to $05 / 05 / 2017)$; winter (08/01/2017 to $09 / 20 / 2017$ ) and spring (10/20/2017 to $12 / 09 / 2017)$. In all, 18 treatments were analyzed. Each treatment consisted of 12 plants, totaling 216 in the experimental field.

For the production of the seedlings we used tubes with a volume of $280 \mathrm{~cm}^{3}$ that were previously sanitized and sterilized with $2 \%$ sodium hypochlorite diluted in water and filled with substrate Tropstrato $\mathrm{HT}^{\oplus}$ Vegetables plus Osmocote Plus $15-9-12$ (3M), at the dosage of $3 \mathrm{~g} \mathrm{tube}^{-1}$, which has the following chemical composition: $\mathrm{N}=15 \%,(7 \%$ ammoniacal and $8 \%$ nitrate), $\mathrm{P}_{2} \mathrm{O}_{5}=9 \%, \mathrm{~K}_{2} \mathrm{O}=12 \%, \mathrm{Mg}=$
$1.3 \%, \mathrm{~S}=5.9 \%, \mathrm{Cu}=0.05 \%, \mathrm{Fe}=0.46 \%, \mathrm{Mn}=0.06 \%$ and $\mathrm{Mo}$ $=0.02 \%$. One seed per tube was used at a depth of approximately $2 \mathrm{~cm}$. The tubes were carried on supports with a capacity of 54 cells, alternately so as not to limit the arrival of light in the seedlings, which could lead to their etiolation.

\section{Climatic data}

Throughout the experimental period, average temperatures were monitored within the greenhouse by a Model 200 Data Logger (WatchDog). The climatic data of the average temperatures in the 50 days of each evaluation inside the greenhouse are presented in Fig 4 . It can be observed that in autumn, there was a variation from 22.7 to $33.3^{\circ} \mathrm{C}$, with averages of $29.75{ }^{\circ} \mathrm{C}$. In winter, the variation was from 20.4 to $28.7 \stackrel{\circ}{\circ}$ and the average of $25.32 \stackrel{\circ}{\circ}$. In spring, it varied

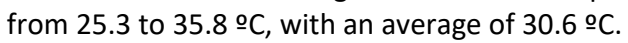

\section{Assessment of characteristics}

At the end of each experimental period, at 50 days after sowing, the seedlings were evaluated for the following morphological characteristics: plant height $(\mathrm{PH})$, using graded ruler in $\mathrm{cm}$ from the stem to the apical bud; stem diameter (SD) in $\mathrm{mm}$, measured $2 \mathrm{~cm}$ above the edge of the tube, with a digital meter of Metrotools, model MPD-150; leaf area (LA), expressed in $\mathrm{cm}^{2}$, estimated with LI-COR leaf area meter, model LI-3100C; length of the root system, measured from the base of the stem to the largest root length (LRS), in $\mathrm{cm}$, with graduated ruler; dry mass of the aerial part (DMAP); dry mass of the root system (DMRS) and total dry mass (TDM), expressed in $g$ and Dickson quality index (DQI), according to Dickson et al. (1960), obtained by equation 1 .

$$
\mathrm{DQI}=\frac{\mathrm{TDM}}{\frac{\mathrm{PH}}{\mathrm{SD}}+\frac{\mathrm{DMAP}}{\mathrm{DMRS}}}
$$

The DMAP and DMRS were obtained after the seedlings were dried in a forced air circulation oven at 65 으 for 72 hours and weighed in an electronic scale with an accuracy of $0.001 \mathrm{~g}$. The TDM was obtained by the sum of DMAP and DMRS.

\section{Statistical analyses}

All data were submitted to analysis of variance by the $F$ test at $5 \%$ probability. The effects of the irrigation depths for the evaluated characteristics were tested by the $5 \%$ probability $F$ regression analysis. When significant, models that best explained each effect were adjusted. The maximum points were obtained through the primary derivative of the regression equations. The averages of the characteristics related to the planting season were compared by the Tukey test at $5 \%$ probability. All the statistical analyzes were performed with software R (R CORE TEAM, 2018), with scripts developed for the data package "ExpDes.pt" version 1.2 (FERREIRA et al., 2010).

\section{Conclusions}

The production of Common Bahia genotype cocoa seedlings (Theobroma cacao L.) is more effective with the application 
of the irrigation depth of $9.44 \mathrm{~mm} \mathrm{~d}-1$, attesting the best development and the highest quality of the plants.

\section{References}

Agrianual - Anuário da Agricultura Brasileira (2017). São Paulo: FNP, Consultoria e Comércio. 315-320.

Araque $\mathrm{O}$, Jaimez RE, Tezara W, Coronel I, Urich R, Espinoza W (2012) Comparative photosynthesis, water relations, growth and survival rates in juvenile criollo cacao cultivars (theobroma cacao) during dry and wet seasons. Expl Agric. 48: 513-522.

Binotto AF, Lúcio AD, Lopes SJ (2010) Correlations between growth variables and the Dickson quality index in forest seedlings. Cerne. 16: 457-464.

Dias L A S (2001) Melhoramento genético do cacaueiro. Viçosa: Funape. 578p.

Dickson A, Leaf AL, Hosner JF (1960) Quality appraisal of white spruce and white pine seedling stock in nurseries. Forest Chronicles. 36: 10-13.

Ferreira E B, Cavalcanti P P, Nogueira D A (2018) Package 'ExpDes.pt'.

Gomes J M, Couto L, Leite H G, Xavier A, Garcia S L R (2003) Crescimento de mudas de Eucalyptus grandis em diferentes tamanhos de tubetes e fertilização N-P-K. Revista Árvore. 27: 113-127.

Hadley P, Acheampong K, Pearson MJE, Weis E (1994) The effects of environmental factors on cherelle wilt in cocoa grown in controlled environments. In: Proceedings of the $11^{\text {th }}$ International Cocoa Research Conference, pp 661-666 IBGE - Instituto Brasileiro de Geografia e Estatistica. Statistics on agricultural production; 2018. (Accessed 10 July 2018) Available:https:// sidra.ibge.gov.br/

Köppen W (1936) Das geographische system der klimate. In: Köppen GW.; Geiger MR. (eds.), Handbuch der Klimatologie, Berlin: Gebrüder Bornträger.

Lahive F, Hadley P, Daymond AJ (2019) The physiological responses of cacao to the environment and the implications for climate change resilience. A review. Agronomy for Sustainable Development. 39: 1-22.
Larcher W (1995) Physiological plant ecology. 3. ed. New York: Springér-Verlag. 505 p.

Lima S S, Spaggiari C A, Patrocínio N G R B, Silva R A, Santos R S G, Gramacho K P (2018) Favorabilidade, distribuição e prevalência da vassoura-de- bruxa do cacaueiro no estado do Espírito Santo, Brasil. Agrotrópica. 30: 5 - 14.

Lopes JLW, Guerrini IA, Saad JCC. (2007) Qualidade de mudas de eucalipto produzidas sob diferentes lâminas de irrigação e dois tipos de substrato. Revista Árvore. 31: 835843.

Melo AS, Costa CX, Brito MEB, Viégas PRA, Silva Júnior CD (2007) Produção de mudas de mamoeiro em diferentes substratos e doses de fósforo. Revista Brasileira de Ciências Agrárias. 2: 257-261.

De Jesus WC, Vale FXR, Coelho RR, Costa LC (2001) Comparison of Two Methods for Estimating Leaf Area Index on Common Bean. Agronomy Journal. 93: 989.

Peksen E (2007) Non-destructive leaf area estimation model for faba bean (Vicia faba L.). Scientia Horticulturae. 113: 322-328.

Peixoto CP, Gonçalves JA, Peixoto MFS, Carmo DO (2008) Características agronômicas e produtividade de amendoim em diferentes espaçamentos e épocas de semeadurano recôncavo baiano. Bragantia, 67: 673-684.

R Core Team (2018) R: a language and environment for statistical computing. Vienna: R Foundation for Statistical Computing, Vienna, Austria.

Sena Gomes AR, Kozlowski TT, Reich PB (1987) Some physiological responses of Theobroma cacao var. Catongo seedlings to air humidity. New Phytol. 107: 591-602.

Sodré G A, Marrocos P C L (2009) Manual da produção vegetativa de mudas de cacaueiro. Ilhéus, Bahia: Editus. 46 p.

Taiz L, Zeiger E, Moller I M, Murphy A (2017) Fisiologia e desenvolvimento vegetal. 6. ed. Porto Alegre: Artmed. 858 p.

Vartapetian B B, Jackson M B (1997) Plant Adaptations to Anaerobic Stress. Annals of Botany, 79(suppl 1). 3-20. 